Int. J. Electrochem. Sci., 12 (2017) $1362-1376$

\title{
Non-Enzymatic Glucose Sensors for Sensitive Amperometric Detection Based on Simple Method of Nickel Nanoparticles Decorated on Magnetite Carbon Nanotubes Modified Glassy Carbon Electrode
}

\author{
Nongyao Nontawong, Maliwan Amatatongchai ${ }^{*}$, Purim Jarujamrus, Suparb Tamuang \\ and Sanoe Chairam \\ Department of Chemistry and Center of Excellence for Innovation in Chemistry, \\ Faculty of Science, Ubon Ratchathani University, Ubon Ratchathani, 34190, Thailand. \\ *E-mail: maliwan.a@ubu.ac.th, amaliwan@gmail.com
}

doi: $10.20964 / 2017.02 .47$

Received: 29 November 2016 / Accepted: 19 December 2016 / Published: 30 December 2016

\begin{abstract}
A sensitive and selective non-enzymatic glucose sensor was developed based on magnetite $\left(\mathrm{Fe}_{3} \mathrm{O}_{4}\right)$ and nickel nanoparticles decorated carbon nanotubes ( $\mathrm{Fe}_{3} \mathrm{O}_{4}$-CNTs-NiNPs). $\mathrm{Fe}_{3} \mathrm{O}_{4}$ nanoparticles were in situ loaded on the surface of carboxylated multi-walled carbon nanotubes (CNTs-COOH) by a chemical co-precipitation procedure. Nickel nanoparticles (NiNPs) were prepared through reducing nickel chloride by hydrazine hydrate and then decorated on $\mathrm{Fe}_{3} \mathrm{O}_{4}-\mathrm{CNTs}$ using ultra-sonication. The as-prepared $\mathrm{Fe}_{3} \mathrm{O}_{4}$-CNTs-NiNPs was characterized using transmission electron microscopy (TEM) and $\mathrm{X}$-Ray Diffraction (XRD). Glucose sensor was fabricated using glassy carbon (GC) coated with $\mathrm{Fe}_{3} \mathrm{O}_{4}{ }^{-}$ CNTs-NiNPs composites film. Electrochemical investigations indicate that the $\mathrm{Fe}_{3} \mathrm{O}_{4}-\mathrm{CNTs}$ NiNPs/GC electrode possesses excellent performance in the electrochemical oxidation of glucose at an applied potential of $+0.55 \mathrm{~V}$ (vs. $\mathrm{Ag} / \mathrm{AgCl}$ ) in $0.1 \mathrm{M} \mathrm{NaOH}$ solution. The linear dynamic range for glucose amperometric detection $\left(\mathrm{E}_{\mathrm{app}}=+0.55 \mathrm{~V}\right)$ was observed from $10 \mu \mathrm{M}$ to $1.8 \mathrm{mM}\left(\mathrm{r}^{2}=0.998\right)$ with the sensitivity of $335.25 \mu \mathrm{A} \mathrm{mM}^{-1}$; and a low detection limit of $6.7 \mu \mathrm{M}(\mathrm{S} / \mathrm{N}=3)$. In addition, the fabricated sensor was successfully applied to determine glucose in honey and energy drinks with good results.
\end{abstract}

Keywords: Amperometric sensor; carbon nanotubes; magnetite, nickel nanoparticles; glucose

\section{FULL TEXT}

(C) 2017 The Authors. Published by ESG (www.electrochemsci.org). This article is an open access article distributed under the terms and conditions of the Creative Commons Attribution license (http://creativecommons.org/licenses/by/4.0/). 